\title{
Student's Perception of Cooperative Learning on Their Academic Achievement and Social Development; The Case of Debre Tabor University Social Science and Humanities faculty, Ethiopia
}

\author{
Alebachew Mohammed Legas \\ Faculty of social science and humanities Department of psychology, Debere Tabor university Ethiopia
}

\begin{abstract}
Ministry of education in Ethiopia enforce to implement cooperative learning in all level of education more than other active learning strategy. But still there is continued debate in our university whether it is the most effective pedagogical technique to be used in higher education for overall development of student. To uncover these 61 males and 59 female students of faculty of social science and humanities from four departments through using stratified random sampling. Regarding sampled student composition $66(55 \%)$ of them are group members in both sex, $36(30 \%)$ of them are group leader and $18(15 \%)$ of students are class representative. The data were collected through using questionnaires and analyzed through descriptive and inferential statistics. The finding reviled that first achievement majority of students $104(86.66 \%)$ respond that Cooperative learning made them to score better grade than working individually. Second knowledge improvement (106 (88.33\%) of students agree cooperative learning enhanced their knowledge of the subject matter). Thirdly general evaluation of cooperative learning method $95(79.16 \%)$ of students agree cooperative learning exceeds the advantage of it than its disadvantages. The fourth finding indicate $101(84.16 \%), 105(87.5 \%)$ and $100(83.33 \%)$ of students reported their class participation, communication and self-expression improved respectively. finaly 90 (75\%) of student reported solve disciplinary problem by themselves using cooperative learning. From this finding it was made clear that more than $80 \%$ of students in all dimension of student development were reported as improved.
\end{abstract}

Keywords: Cooperative learning, achievement, knowledge, social development, discipline.

DOI: $10.7176 / \mathrm{JEP} / 10-1-06$

\subsection{Introduction}

Cooperative learning is one of the most widespread and fruitful areas of theory, research, and practice in education. Its history of theory, research, and actual use (beginning at least in 3,000 BC) makes it one of the most distinguished of all instructional practices. Few instructional procedures have such an illustrative history (W. Johnson and T. Johnson 20011999) its immediate roots in the early 1900s when Kurt Koffka proposed that groups were dynamic wholes in which the interdependence among members could vary. In the 1920s and 1930s, Kurt Lewin (the founder of modern day social psychology) refined Koffka's notion, proposing that the essence of a group is the interdependence among members (created by common goals), and that interdependence results in the group being a "dynamic whole" so that a change in the state of any member or sub group changes the state of any other member or subgroup (W. Johnson and T. Johnson 2001 and Stanne, Johnson and Johnson 19 99)

According to W. Johnson, T. Johnson and Stanne (2000) The widespread use of cooperative learning is due to three factors. First, cooperative learning is based solidly on a variety of theories in anthropology, sociology, economics, psychology, and other social sciences. Second, the amount, generalizability, breath, and applicability of the research on cooperative, competitive, and individualistic efforts provide considerable validation of the use of cooperative learning, perhaps more than most other instructional methods. The third factor is the variety of cooperative learning methods available for teacher use, ranging from very concrete and prescribed to very conceptual and flexible.

But there is still continued debate in our university whether it is the most effective pedagogical technique to be used in higher levels of education or not. it was convincing if this case was in early days of this century which the amount and quality of that research were lowest but know greatly accelerated beginning started from early 1970's, and continues finding unabated today (Robert E. Slavin 1998)

Because the past 90 years, nearly 600 experimental and over 100 correlational studies have been conducted comparing the effectiveness of cooperative, competitive, and individualistic efforts by a wide variety of researchers in different decades with different age, subjects and in different settings were proved cooperative learning is a best method (Smith, K.A. 19 96).

\subsection{Statement of the problem}

Most literature states that quality can be judged in terms of input, process and outputs. However, according to Derebssa Dhufera (2006), much discussion of educational quality center mostly on system inputs (provision of teacher, teaching material and other facilities) by forgetting the process. Hence, currently the ministry of education is giving much emphasis for the process and investing on the implementation of active learning which 
even assumed to be cost-effective. Cooperative learning as a main team of active learning were implemented in higher education some years ago. Specially Debre Tabor University, to address the Nation's quest for quality education, has introduced "Innovative Curriculum" from the outset since its foundation.

As the part of this system, different assessment made in the university shows that faculty of social science and humanities is implementing cooperative learning relatively in better condition than other faculties. But it was not supported by scientific research about the perception of student, improvement and benefit they acquired. Rather the inference was made from simple observation, reaction of department heads and higher officials reports which is to qualitative and not systematic. Furthermore, many lecturers within and out of the faculty have been questioning its effectiveness and contribution for the student. In doing So, that it is important to conduct this research and see the interplay between the presumption and the actual practice by posing the following question

1. Does cooperative learning facilitate students' knowledge acquisition, achieving better grade, participating in class, developing self-expression and communication skill?

2. What is students' reaction on cooperative learning?

\subsection{Objective of the study}

The general objective of the study is to examine the students' reaction towards cooperative learning in relation to improving their knowledge, achievement, participation, self-expression and communication skill. And to investigate students' reaction on cooperative learning strategy.

\subsection{Significance of the study}

This study will provide the concrete evidence about the impact of cooperative learning to the multiple benefit for students. In this regard the study will provide a comprehensive image to the faculty as to the overall performance of cooperative learning. In line with this the finding can be taken for further breakthrough.

In the same token the finding can pave a way to devise new strategy to the faculty and the university as well

\subsection{Delimitation}

This study was delimited to faculty of social science and humanities four departments student reaction towards the benefit they acquired from cooperative learning. Thus the study not directly infer from the result or from controlled experiment.

\subsection{Definition of term}

Cooperative learning is an organized and structured way to use small groups (5-7 students) to enhance student learning and interdependence. Students are given a task in the class and or as an assignment, and they work together to accomplish this task.

\section{Methodology}

\subsection{Participant}

The participant of this study were 61 male and 59 female students of faculty of social science and humanities among four departments (Early childhood care and education, geography and environmental study, civics and ethical study and English language and literature) from first year to third year students.

\subsection{Sampling techniques}

From each year level of the four department 14 students ( 4 group leader, 4 male group member, 4 female group member and 2 monitor) were selected by simple random sampling. In doing so, 42 students from ECCE, 14 students from civics and ethical study, 14 students from English language and literature and 52 students from geography and environmental study were selected. The sample comprise a total of $120(25.69 \%)$ students. While in selection to represent each group in the class at least one participant in any forms (group leader or group member or monitor) were included from each group in the class.

\subsection{Data collection instrument}

The data were collected through self-develop questionnaires which have 13 questions. The questionnaires have five parts; 3 questions about achievement, 3 questions about Knowledge acquisition, 2 questions about General evaluation of cooperative method, 3 questions about Class participation, communication and self-expression and 2 questions about Discipline.

\subsection{Validity of the instruments}

To check the validity of instruments the questionnaire was distributed to four department heads and some improvements were made on arrangement, language and reframing statements. 


\subsection{Data collection procedure}

After randomly selected the participant data were collected in the classroom with brief explanation on how to fill the questionnaire.

\subsection{Data scoring}

Positively worded item scored as $1=$ disagree, 2 undecideds and $3=$ agree and negatively worded item scored as $1=$ agree, 2 undecideds and $3=$ disagree

\subsection{Data analysis}

Descriptive analysis was used in frequency and percentage to analyze students' response to the benefit of cooperative learning to students' knowledge acquisition, achievement, participation, communication skill and inferential statistics (Anova and post hock analysis) to see difference among different category of respondent.

\section{Data analysis and discussion}

Table 1. General presentation of student response

\begin{tabular}{|c|c|c|c|c|c|c|c|}
\hline & \multirow[t]{2}{*}{ Questions } & \multicolumn{6}{|c|}{ Response } \\
\hline & & disagree & $\%$ & undecided & $\%$ & agree & $\%$ \\
\hline \multirow{3}{*}{$\begin{array}{l}\text { student } \\
\text { achievement }\end{array}$} & $\begin{array}{l}\text { 1. Cooperative learning made me to } \\
\text { score better grade than working } \\
\text { individually }\end{array}$ & 15 & 12.5 & 1 & 0.8 & 104 & 86.6 \\
\hline & $\begin{array}{l}\text { 2. cooperative learning brought } \\
\text { better grade than the } \\
\text { individualistic } \\
\text { approaches } \\
\text { working }\end{array}$ & 18 & 15 & 2 & 1.6 & 100 & 83.3 \\
\hline & $\begin{array}{l}\text { 3. Cooperative learning helps our } \\
\text { class students to achieve better } \\
\text { grade }\end{array}$ & 11 & 9.16 & 2 & 1.6 & 107 & 89.1 \\
\hline \multirow[t]{3}{*}{$\begin{array}{l}\text { Knowledge } \\
\text { improvement }\end{array}$} & $\begin{array}{l}\text { 1. cooperative learning enhanced } \\
\text { my knowledge of the subject }\end{array}$ & 10 & 8.33 & 4 & 3.3 & 106 & 88.3 \\
\hline & $\begin{array}{l}\text { 2. Assignment given in cooperative } \\
\text { setting enhanced my knowledge } \\
\text { of the subject than given } \\
\text { individually }\end{array}$ & 39 & 32.5 & 2 & 1.6 & 79 & 65.8 \\
\hline & $\begin{array}{l}\text { 3. I easily understand and find class } \\
\text { work given individually then in } \\
\text { cooperative setting }\end{array}$ & 84 & 70 & 4 & 3.3 & 32 & 26.6 \\
\hline \multirow{3}{*}{$\begin{array}{l}\text { Class } \\
\text { participation, } \\
\text { communication } \\
\text { and self- } \\
\text { expression }\end{array}$} & $\begin{array}{l}\text { 1. Group class work improved my } \\
\text { participation }\end{array}$ & 15 & 12.5 & 4 & 3.3 & 101 & 84.1 \\
\hline & $\begin{array}{lll}\text { 2. } & \begin{array}{l}\text { Cooperative } \\
\text { improving my } \\
\text { with students }\end{array} & \text { communication } \\
\end{array}$ & 13 & 10.83 & 2 & 1.6 & 105 & 87.5 \\
\hline & $\begin{array}{l}\text { 3. Cooperative } \\
\text { improving my ability of self- } \\
\text { expression }\end{array}$ & 18 & 15 & 2 & 1.6 & 100 & 83.3 \\
\hline \multirow[t]{2}{*}{ Discipline } & $\begin{array}{l}\text { 1. Cooperative learning helps us to } \\
\text { solve problems happened in class } \\
\text { by our self }\end{array}$ & 23 & 19.16 & 7 & 5.8 & 90 & 75 \\
\hline & $\begin{array}{ll}\text { 2. } & \begin{array}{l}\text { Cooperative learning able } \\
\text { students to have good discipline }\end{array} \\
\end{array}$ & 18 & 15 & 4 & 3.3 & 98 & $81 . .6$ \\
\hline \multirow{2}{*}{$\begin{array}{l}\text { General } \\
\text { evaluation of } \\
\text { coop method }\end{array}$} & $\begin{array}{l}\text { 1. The disadvantage of cooperative } \\
\text { learning exceeds the advantage }\end{array}$ & 95 & 79.16 & 9 & 7.5 & 16 & 13.3 \\
\hline & $\begin{array}{l}\text { 2. cooperative learning is drowning } \\
\text { me back to work in my full } \\
\text { potential }\end{array}$ & 85 & 70.83 & 2 & 1.6 & 33 & 27.5 \\
\hline
\end{tabular}

\subsection{The contribution of cooperative learning to students' achievement}

Though it is difficult to analyze the effect of cooperative learning apart from the other contributing factors in survey research, one way to study is triangulation of student reflection on the outcome of the method. It was a 
known fact that cooperative learning improves the academic ability and achievement of students by different studies. Table two below state students' response to the contribution of cooperative learning in their achievement. For the first question majority of students $104(86.66 \%)$ respond that Cooperative learning made them to score better grade than working individually and only $15(12.5 \%)$ of respondents disagree. For the second question which measures students' comparative interest of individualistic and cooperative work in their achievement of class, $100(83.33 \%)$ were in favor of cooperative learning and only $20(16.67 \%)$ stand against cooperative learning and in favor of individualistic approach. Finally, the response for third question majority of 107 (89.1\%) believes that Cooperative learning helps their class to achieve better grade. From this in all three-dimension students prefer and believe that cooperative learning is assisting to achieve better grade to themselves and to their class and comparatively better than working individually with no major difference in department, sex and responsibility of respondents.

To confirm this one-way ANOVA was analyzed and there is no statistically significant difference between responsibility of student $\mathrm{p}<0.05[\mathrm{~F}(2,117=2.67, \mathrm{p}=.073]$ and departments $\mathrm{p}<0.05[\mathrm{~F}(23,116=.481, \mathrm{p}=.696]$. But there is statistically significant difference between year levels $p<0.05[F(2,117=4.13, p=.018]$ on student response to contribution of cooperative learning to their achievement. The post hoc analysis in page 9 shows this difference. Second year student have lower attitude towards cooperative learning contributed to their achievement than first year and second year students illustrated below in table 4 .

From this we conclude that majority of students believe that contribution of cooperative learning to their academic achievement with no difference in sex, department, category of responsibility and year level. but relatively second years' students were found in disagreement than first year and third year which require further investigation and intervention to this year level.

\subsection{Cooperative learning and Knowledge improvement}

The basic assumption of cooperative learning is that they can improve their knowledge by sharing of different knowledge and experience among the group members.

For the question one that assess whether cooperative learning enhanced their knowledge of the subject matter $106(88.33 \%)$ of student agree but $10(8.33 \%)$ disagree and $4(3.34 \%)$ undecided about it, thus significantly larger proportion of students without major difference in sex, year level, responsibility and department variation, believe that their achievement was progressed by cooperative learning. Regarding the comparison of individualistic and cooperative learning set assignment in their knowledge contribution mentioned in question 2, $79(65.83 \%)$ of students were agree in favor of cooperative learning set, whereas $39(32.5 \%)$ of students disagree, which means that they acquire better grade in their individual assignment than in group assignment. This figure is similar in that one third of all departments, sex, and responsibility of students. However, second year $24(45.28 \%)$ of student and third year $6(46.15 \%)$ of student are indicated by disagreement that they get better knowledge in assignment given individually than cooperative learning.

Thus, this finding indicates that probably first year students are curies and fearful of the teacher and system and work together so that they acquire better knowledge. when they familiarize with teacher behavior and system specially if the teacher not maintain individual accountability by individually measuring each member contribution and understanding the content of assignment, they will have left the work to few group members consecutively less contributes to their group member knowledge. In other way using both approaches also a best strategy in compromising the weakness of one method.

\subsection{General evaluation of cooperative method}

Student were asked in table below to show their stand whether cooperative learning disadvantage exceeds over the advantage and whether it drowns them back to work in their full potential and their response were analyzed below

As indicated in the above table, to the question 1, the disadvantage of cooperative learning exceeds the advantage, $95(79.16 \%)$ of student disagree, $16(13.34 \%)$ and $9(7.5 \%)$ of student disagree and undecided respectively. Thus, from this it is possible to infer that majority of student believe that the advantage of cooperative learning exceeds the disadvantage. In comparison $2^{\text {nd }}$ year student $13(24.52)$ are reported the disadvantage of cooperative learning exceed the advantage than third year 0 and first year 3 (5.55\%). Group member $11(16.66 \%)$ than group leader $4(11.11 \%)$ and class representatives $1(5.5 \%)$

For the question, cooperative learning is drowning me back to work in my full potential $85(70 \%)$ of students respond in disagreement and $33(27.5 \%)$ in agreement. Hence though two third of the respondent shows that cooperative learning did not draw them back to work in their full potential, still one third of respondent show it draw them back though they believe it significantly contribute to their achievement and knowledge. This might be related with the inappropriate implementation of cooperative learning affects its effectiveness. 


\subsection{Class participation, communication and self-expression}

Since the university are using cooperative learnings as an engine to the active learning process, it is expected to improve student class participation as main out comes and improve student communication and self-expression. According to Datson (2001) within the framework of cooperative learning groups students learn how to interact with their peers and improve to involvement with the school communities.

Table 1 ; indicate that $101(84.16 \%)$ of students reported their class participation were improved, 105 $(87.5 \%)$ of students proved Cooperative learning is improving their communication with students and finally $100(83.33 \%)$ of student responded that Cooperative learning is improving their ability of self-expression.

\subsection{Discipline}

Table 1 show that 90 (75\%) of students reported Cooperative learning helps them to solve problems happened in class by themselves. So that beyond the learning it contributed in establishing good relationship among students. In line to this for question two which assess Cooperative learning able students to have good discipline was greed by $98(81.66 \%)$ of students

\section{Conclusion}

It was made clear that more than $80 \%$ of students in all dimension of student development of knowledge, achievement, participation, self-expression, discipline and communication were reported as improved (contributed for their improvement) because of cooperative learning set even majority of students were indicate the advantage of cooperative learning exceeds the disadvantage and they prefer cooperative learning than individualistic methods with no major difference in department, sex, year level and responsibility of respondents.

\section{Recommendation}

* Since it was proven by students, cooperative learning was highly contributing for their academic and social development the teacher should get out to the unnecessary debt of the importance of cooperative learning

* with this Mach effort made by the teacher and student with little scientific procedure of cooperative learning we are able to accomplish many achievements. So that We should strengthen our practice with the scientific implementation of cooperative learning and enhancing the fruits of cooperative learning to our students.

\section{Acknowledgement}

I would like to thank Ato Behayilu Atinafu (dean of faculty of social science and humanities) for initiating the study to be conducted, critical comments and assisting for its successful completion and the four department heads Ato Mebrate Gedife (ECCE department head), Ato Antehunegn Atanaw (English language and literature department head), Ato Amin Mama (Civics and ethical education department head) and w/rt Ergo (Geography and environmental study department head) for their constructive comment for the questionnaires and allotting time for collecting the data in their department

\section{References}

David W. Johnson, Roger T. Johnson, and Mary Beth Stanne (2000) Cooperative Learning Methods: A MetaAnalysis.

Derebssa Dufera Serbessa (2006), Tension between Traditional and Modern Teaching-Learning Approaches in Ethiopian Primary Schools. Addis Ababa University.

Eanie M. Dotson (2001) Cooperative Learning Structures Can Increase Student Achievement. Kagan Online Magazine,

Johnson, D. W., \& Johnson, R. T. (1999). Learning together and alone: Cooperative, competitive, and individualistic learning (5th ed.). Boston: Allyn \& Bacon.

Robert E. Slavin (19 98). Research on Cooperative Learning and Achievement: What We Know, What We Need to Know. Johns Hopkins University. Educational Research and Improvement, U.S. Department of Education (No. OERI-R-117-D40005).

Smith, K.A. (19 96). Cooperative learning: Making "group work" work. San Francisco.

Stanne, M., Johnson, D. W., \& Johnson, R. T. (1999). Social interdependence and motor performance: A metaanalysis. Psychological Bulletin, 125, 133-154

W. Johnson and T. Johnson (2001). Learning Together and Alone: An Overview. University of Minnesota. Asia Pacific Journal of Education, 22, (1). 95-105 